\title{
Aristotelian Character Friendship as a 'Method' of Moral Education
}

\author{
Kristján Kristjánsson ${ }^{1}$ \\ Published online: 19 March 2020 \\ (c) The Author(s) 2020
}

\begin{abstract}
The aim of this article is to make a case for Aristotelian friendship as a 'method' of moral education qua mutual character development. After setting out some Aristotelian assumptions about friendship and education (and revising some of those) in the "Aristotle and Beyond: Some Basics about Character Friendship and Education"section, I devote the "Role-Model Moral Education Contrasted with Learning from Character Friends" section to role modelling and how it differs from the idea of cultivating character through friendships. "The Mechanisms of Learning from Character Friends" section then explores the mechanisms of Aristotelian friendship education directly: those identified by him and those which can be elicited more obliquely from his texts. I end in the "Concluding Remarks and Classroom Applications" section with some reflections on how this model of friendship as a moral method could be applied in current educational contexts. While the idea of character friendship as an educational method comes with many assets, it also imports various liabilities that may lead to painful friendship terminations. I have put the spotlight on those liabilities in two previous articles. In contrast, the goal here is to impart a new edge and added force to the idea that a certain Aristotle-defined type of deep friendships may have a unique role to play in facilitating moral growth, above and beyond other developmental learning mechanisms.
\end{abstract}

Keywords Friendship as an educational method $\cdot$ Aristotle $\cdot$ Character friendships $\cdot$ Role models $\cdot$ Mechanisms of friendship education

\section{Introduction: Friendship and Moral Education}

I deliberately chose a provocative title for this article by referring to friendship as a 'method' of moral education, albeit in scare quotes. The title is provocative for two reasons. One is that nowhere does Aristotle himself refer to his highest type of friendship, namely 'character friendship' (nor indeed any lower type), as a 'method'. However, bear in mind that the Nicomachean Ethics is a manual on making wise choices and living well,

Kristján Kristjánsson

k.kristjansson@bham.ac.uk

1 Jubilee Centre for Character and Virtues, School of Education, University of Birmingham,

Birmingham B15 2TT, UK 
and there is a strong educational thread running through it, from beginning to end. I will be arguing later that moral education (or, more narrowly construed, the cultivation of good character) is the raison d'être of character friendship. Lubricating the slide from that argument to the use of the word 'method' is the fact that two of the ten books of the Nicomachean Ethics and nearly a third of the Eudemian Ethics are devoted to friendship's recognisably ethical nature, its educational ramifications and the proper or improper reasons for its termination. Aristotle wrote all of that before the time of explicit theories of educational methods. However, only plodding docility before these ancient texts would debar us from giving his account of friendship a more direct educational spin by couching it in the current language of educational methods.

The second reason why the title may seem provocative is that whereas the standard view of friendship — dating back to no other than Aristotle himself-is that friendship has intrinsic value, talk of it as a 'method' smacks of instrumentalisation: the reduction of its value to extrinsic benefits. However, here is a helpful analogy. It is well known that Aristotle mentions music as a method of moral education (or, more precisely, of emotion regulation which is a foundation of balanced character development) in his Politics. It could well be that music only carries those benefits for people who, antecedently, appreciate the intrinsic worth of music. There is thus no incoherence in supposing that the same thing can have both non-instrumental and instrumental value (take health as another telling example). For character friendship, at least, as we see later, Aristotle makes the strong demand that it not be entered into directly for its presumed utility in improving character; we have to grant its intrinsic value first by loving the friend for her own sake.

Now, while reams have been written about Aristotle's theory of friendship and there is a current bandwagon of interest in Aristotelian or Aristotle-inspired methods of character education, few attempts have been made to bring the two literatures together (as correctly pointed out by Hoyos-Valdés 2018), at least for practical educational purposes as distinct from moral theoretical ones (see Cooper 1977, and Brewer 2005, for examples of the latter). At the same time, another related Aristotelian method, about which Aristotle actually says much less, namely the emulation of moral exemplars (aka moral role modelling), has become the hottest ticket in town, with major recent contributions from within moral philosophy (Zagzebski 2017), moral psychology (Damon and Colby 2015), moral education (see a special issue of Journal of Moral Education, ed. by Campodonico et al. 2019) and even popular trade books (Brooks 2015). I am only able to offer educated guesses about the reasons why. Perhaps modern amoral (e.g. aestheticised, see Nehamas 2016) conceptions of friendship have blinded us to its moral value; perhaps role-model methods are easier to administer in formal educational contexts as 'interventions' than the cultivation of (the right kind of) friendship; perhaps friendship as a 'method' cannot be fully understood or operationalised without making sense simultaneously of advanced phronesis development, which has baffled many moral educators because of its sheer complexity (Darnell et al. 2019).

Whatever the reason, the main aim of this article is to make a case for Aristotelian friendship as a method of moral education qua mutual character development. After setting out some Aristotelian assumptions about friendship and moral education (and updating/ revising those where necessary) in the following section, I devote the third section to role modelling and how it differs from the idea of cultivating character through friendships. The fourth section then explores the mechanisms of Aristotelian friendship education directly: those identified by him and those which can be elicited more obliquely from his texts. I conclude in the final section with some reflections on how this model of friendship as a 'moral method' could be applied in current educational contexts. 
The idea of character friendship as a moral educational method comes, I argue, with many assets. However, it also imports various liabilities that may lead to (often painful) friendship ruptures. In two previous articles I have put the spotlight on those liabilities: both the general shortcomings of Aristotle's fairly romanticised account of character friendship (Kristjánsson 2019) and how those shortcomings may play out in the educational arena: arresting rather than furthering moral development (Kristjánsson 2020a). Because of this previous ground-clearing work-which I refer to at various junctures but refrain from reproducing here-I allow myself to be somewhat upbeat in this article. The current aim is simply to impart a new edge and added force to the idea that a certain Aristotledefined type of deep and close friendships may have a unique role to play in facilitating moral growth, above and beyond, for instance, methods of moral-exemplar emulation. That this type of friendship also has its shadow sides is a topic no less worthy of examination and caution, but such an examination is not on today's agenda.

\section{Aristotle and Beyond: Some Basics about Character Friendship and Education}

Friendship for Aristotle is conscious 'reciprocated goodwill' (1985, p. 210 [1155b32-35]). It assumes three main types, where the first two (friendships for pleasure and utility) are 'incomplete'-because of their essentially extrinsically valuable and transitory naturesbut the most developed type (character friendships) is 'complete' because of its unique intrinsic and enduring nature (1985, pp. 211ff [1156a6ff]). Notably, pleasure and utility friendships are necessary for smooth human association, and they will continue even among those who have formed character friendships. While 'base' people can actualise them, but not the complete type, 'good' (namely virtuous) people enjoy all three types in different contexts but most specifically the complete type (1985, pp. 212 and 216 [1156b6-8 and 1157b1-4]). Aristotle makes it a necessary conceptual condition of all the three (genuine) types of friendship that to 'a friend [...] you must wish good for his own sake' (1985, p. 210 [1155b31-32]). Nevertheless, once the raison d'être of the two incomplete types (of being mutually advantageous or mutually pleasurable) is lost, they dissolve fairly easily (as opposed to character friendship) despite the intrinsic goodwill which sustains them while they last.

Apart from the features they share with the incomplete types, character friendships present some unique features of their own. For example, they involve (a) spending time together in shared activities, (b) sharing joys and sorrows, (c) loving the friend for her own sake in the form of loving her character (as her set of virtues), (d) soulmateship in the strong sense of being 'related to his friend as he is to himself, since the friend is another himself' (1985, p. 246 [1166a30-33]; cf. pp. 260 and 265 [1170b6-7; 1172a32-34]) and (e) viewing the friendship as intrinsically valuable to the extent of seeing the friend as irreplaceable, not only painfully replaceable as in the more developed forms of utility friendships.

Notice that apart from the clause 'in the form of loving her character...' in (c), all these features do, or at least could, show up as attributes of any so-called 'deep' or 'close' friendships as they are commonly understood nowadays by those without any ready-made Aristotelian philosophy in their pockets. This is why, although the present article happens to be set in the context of Aristotle's friendship typology, it is not necessary to buy into all the conceptual conditions that Aristotle places on his narrowly defined kind of 'deep' 
friendships to appreciate most of the points made in what follows as being about the moral educational role of any such friendships - more broadly specified. That said, even notions of 'deep' friendships as commonly understood by lay people, while not explicitly Aristotelian, tend to owe a lot to the Aristotelian account, as almost all historical discussions of friendships - which have then percolated down into everyday understandings - take Aristotle as their point of departure.

The above list of the defining features of character friendships notwithstanding, and especially the unique Aristotelian one of loving the friend's character, we have not really established yet what character friendships are essentially for, in the same sense as we did above in noting the raison d'être of pleasure and utility friendships. The standard answer in current psychological theories of deep friendships is to fasten on the psychological intimacy involved in features (b) and (d) and postulate that the aim of friendship is to utilise this intimacy in the service of psychological wellbeing (typically defined subjectively and non-morally) and psychological health (critiqued e.g. by Fowers and Anderson 2018). The Aristotelian answer, in contrast, draws on (c) and especially the 'loving her character' clause. The Aristotelian raison d'être of character friendships is, arguably, both moral and educational. The aim of such friendships is not only the love of character per se, but loving it in the service of mutual character development. Character friends become 'better from their activities and their mutual correction' as 'each moulds the other', and through this mutual moulding they become 'more capable of understanding and acting' (1985, pp. 266 and 208 [1172a11-14 and 1155a15-16]). Friendship of this kind educates by being, in various ways, knowledge-enhancing, virtue-enhancing and life-enhancing, through the friends acting as each other's procreators on the trajectory towards full phronesis (Telfer 1970-1971, pp. 239-240). The dynamics of how exactly this happens, and how it can be made to happen more effectively throughè educational interventions, is a topic for the final two sections. For the time being, we can make do with Brewer's crisp illumination of this raison d'être as having to do with how 'friends draw each other out and participate in the fine-toothed articulation of each other's character' (2005, p. 726).

Three caveats are in order at this juncture. The first is that this account of the raison d'être of Aristotelian character friendships is not indisputable because Aristotle never says explicitly that the fundamental aim of such friendships is developmentalcum-educational. However, given the remarks at the beginning of this article about the educational nature of his ethical works, readers will know where I am coming from. Apart from that general point, Aristotle says quite a lot about how friendship in fact educates, and for a dyed-in-the-wool naturalist like himself, there is a short step from 'is' to 'ought'. Second, although I fasten on character friendship is this article, there would be a case for arguing that the lower types of friendships, especially friendship for utility, can have moral educational value also. For example, a utility friend may help me to stay self-controlled when facing tribulations rather than lapsing into despondency or vice (say, by deciding to end my life). Third, non-character based accounts of deep friendships are also capable of postulating strong educational aims. For example, aestheticised accounts, with historic representations in authors as distinct as Montaigne and Nietzsche, could - in principle - assume that such friendships help develop our aesthetic sensibilities and sensitivities in a way that is educationally salient, albeit amoral. Nevertheless-in practice-proponents of aestheticised accounts tend to downplay friendship's educational role. For example, Nehamas (2016, p. 199) says that even close friendships 'are often less edifying than the rhetoric that surrounds the institution would have them be' and that 'the bulk of our interactions with friends are, at least at first sight, trivial and inconsequential'. The worry seems to be here that if one acknowledges 
education as the raison d'être of deep friendship, one risks letting a moralised (Aristotelian or quasi-Aristotelian) account slip in through the back door.

Despite his famous academic patricide on Plato, Aristotle shares his mentor's penchant for defining concepts—initially at least—with respect to their most perfect instantiations. Thus, Aristotle makes an early comment about complete (namely, characterbased) friendships (1985, p. 212 [1156b6-8]) that has often been interpreted to mean that such friendships are possible only between people who are not only, as he says, 'similar in virtue', but also equal in social standing, and even already both of perfect virtue (namely fully fledged phronimoi). While that is clearly his ideal instantiation, Aristotle spends considerable space in the following discussion delineating friendships that are complete while not perfect: namely, character friendships among people who are socially unequal in various ways-given the specific power dynamics in ancient Greek society-and/or on the path towards full phronesis rather than phronimoi graduates already. As Cooper adamantly puts it, 'it is clear that Aristotle is willing to countenance a virtue-friendship where both parties are quite deficient with respect to their appropriate excellences' (1977, p. 628). Nevertheless, the relevant parties cannot be too bad (fully vicious) nor indeed too good (divinely virtuous like gods) for the character friendship to work as veritable soulmateship.

All these conceptual demarcations create in the end what I have elsewhere called a 'zone of proximal development of character friendships': the zone in which moral (character) education can take place (Kristjánsson 2020a). Somewhat paradoxically, people at the very top of this zone - the perfect phronimoi friends - threaten to undermine my thesis about mutual character development as the raison d'être of character friendship, because-as perfect ethical agents - the phronimoi, ex hypothesi, need no further development. Rather, they 'affirm each other's evaluative outlooks 'unreservedly and unconditionally' and engage in a 'running appreciation' of their 'jointly produced sensibilities' (Brewer 2005, pp. 726, 730, 758). It is worth correcting Aristotle's idealism here, pointing out that he should have been more mindful of his own examples of how even the highly virtuous can go wrong (Kristjánsson 2020a, cf. Curzer 2005). So, on a plausible Aristotelian account (although not Aristotle's own), the phronimoi would still need lifelong moral education in the ordinary sense to keep their character boats steady. Furthermore, the phronmoi are, through their character friendships, engaging in flourishing-enhancing activities by enjoying the specific kinds of pleasures that attach themselves, subsequently, to successful characterological achievements. They are, so to speak, savouring the icing on the educational cake, which may also count as an educational activity of a sort: namely its culmination.

More relevant for present purposes are, however, three cohorts of people-all budding rather than fully developed phronimoi-who engage in character friendships that are essentially moral educational on a more standard understanding. Those are people of (a) equal social status who are either (a1) equal in virtue or (a2) unequal in virtue, and (b) people of unequal social status who are unequal in virtue. Notably, Aristotle presupposes that inequality of social status implies inequality in virtue although equality of social status does not guarantee virtue equality: a highly contentious assumption (which must be understood against the background of Aristotle's own highly stratified society; see Kristjánsson 2019). Consider, for (a), two undergraduates who become friends as freshmen and help each other grow in virtue, either because, (a1) being equal in virtue at the outset, they share experiences on parallel tracks, or (a2) because the one who is more virtuous at the beginning helps the other catch up while also developing herself. For (b), consider a professor/ teacher/mentor and a student who both grow morally from their mutual interactions but 
where the former has more to give in terms of moral knowledge, yet more to take back in terms of morally deserved and commendable gratitude.

Empirically minded educators will obviously want to know what age ranges we are talking about here. It would be untenable, according to Aristotle, to claim that very young children are capable of character friendship (although Aristotle is usually not precise in giving age limits for developmental transitions). Such friendship presupposes some minimal 'comprehension or [at least] perception' of the moral character of the other to be cherished and admired (Aristotle 1985, p. 230 [1161b26-7]). Other than that, Aristotle is at his most elusive here. He does say that, while the old and 'sour' are prone to mere utility friendships in order to make sure they are cared for, the cause of friendship between young people 'seems to be pleasure' (1985, p. 212 [1156a31-33], and 216 [1157b14-15]; cf. 1935 , p. 371 [1236a35-37]). On the other hand, he also states that 'the young need [friendship] to keep them from error' (1985, p. 208 [1155a10-13]), and he is clearly not talking about friendship for pleasure there. He later takes the example of parent-child associations as a paradigmatic case of unequal friendships, and he seems to be talking about character friendships there because he says that this sort of friendship 'also' includes pleasure and utility (1985, p. 231 [1162a4-9]). Despite this textual evidence, the standard view is that Aristotle did not consider children capable of character friendships (see e.g. Jacquette 2001) because they do not really possess virtues yet as relatively stable (but amenable to further development) traits of character. The apparently clear reference to parent-child friendships is then typically written off on grounds of the fact that the word philia in ancient Greek could also cover parental love.

This article is not meant to constitute an exercise in Aristotelian exegesis, but I cannot resist the temptation to remark that the standard exegetical view seems fairly weak. In the Rhetoric, Aristotle unambiguously refers to some 'virtues' that virtuous adults should ideally possess but do come more easily to young people for reasons of developmental psychology. The young are thus typically open-minded and optimistic, tending to look at the good side rather than the bad side of things, as they have not yet 'seen much wickedness'. They trust others readily 'because of not yet having been much deceived'. They are also more courageous and guileless than the old are, and have more exalted notions, not having yet been 'worn down by life'. Moreover, they are fonder of their friends than older people are and have not come to value them for their usefulness (2007, pp. 149-150 [1389a16-b3]). The virtues referred to here are obviously not phronesis-infused virtues, but rather what Aristotle would designate as 'merely habituated' ones, but they are virtues nevertheless, making up character (cf. Kristjánsson 2007, Chap. 8). I think Aristotle would most likely have seconded the observation made by one of Gabriel Garcia Marquez's characters that 'one does not love one's children just because they are one's children but because of the friendship formed while raising them' (1988, p. 211).

Parent-child friendships aside, and whatever Aristotle's view may have been, current empirical evidence seems to indicate that, at least in late childhood, children may be capable of mutually edifying character friendships (cf. Healy 2011, for an even-handed discussion of the literature, pro and con). For example, an empirical study of 9-10 year old children in the UK (Walker et al. 2016) revealed that those children often claimed to identify and choose friends on the grounds of their moral qualities, more specifically virtues such as honesty, generosity, helpfulness and kindness. Indeed, 'the language of virtue seemed to come naturally to many of the children' (2016, p. 296; cf. Wagner 2019, for similar findings about early adolescents). Notably, the authors refer to the sort of friendship described by many of their respondents as 'eudaimonic friendship', perhaps to avoid the strictness of the criteria associated with Aristotelian 'character friendship' and of becoming embroiled 
in exegetical debates. Nevertheless, I consider their evidence to add backbone to the view that the educative value of character friendship can emerge prior to adolescence-a view which also suggests a more optimistic view of the usefulness of reflective moral education among fairly young people than that often ascribed to Aristotle (e.g. by Burnyeat 1980).

\section{Role-Model Moral Education Contrasted with Learning from Character Friends}

Hoyos-Valdés (2018, p. 66) argues in a challenging paper that the 'overemphasis on role models is misguided and misleading, and a good antidote draws on the Aristotelian concept of character friendship'. What she is referring to here is the discourse in current (mostly Aristotle-inspired) character-education discourse on how we develop our virtues through engagement with inspiring individuals. As I noted at the beginning, this discourse is-in direct contrast to Aristotle's own emphasis-almost exclusively about role-model education as distinct from learning from character friends. While, as always, there is no reason to take Aristotle as gospel on any of those issues, his conceptualisations are well suited, as ever, to serve as starting points of the discussion, if only because of their historical importance.

The current discourse on role-model education, insofar as it is conducted within a character-education tradition, typically draws on Aristotle's well-defined emotion of emulation (zelos), or emulousness as a trait. Emulation, says Aristotle, is

a kind of distress at the apparent presence among others like him by nature, of things honoured and possible for a person to acquire, [with the distress arising] not from the fact that another has them but that the emulator does not (thus emulation is a good thing and characteristic of good people, while envy is bad and characteristic of the bad; for the former [person], through emulation, is making an effort to attain good things for himself, while the latter, through envy, tries to prevent his neighbour from having them) (2007, p. 146 [1388a29-38]).

Emulation, as we gradually learn from Aristotle (cf. Kristjánsson 2007, Chap. 7), is an unusual emotion in that, although its valence is overall negative, that is distressful, with the pain being caused by the emulator's perceived inferiority vis-à-vis the emulated person (i.e. the role model, in today's language), it is overall positively evaluating in that the emulator prefers the option of the role model retaining her superiority over the option of surpassing her by making her inferior. What the emulator wants is just to equal the role model, not to supersede her or take anything away from her; this is why emulation must be strictly distinguished from the overall negatively evaluating emotions of envy and begrudging spite.

Aristotle is not terribly enlightening in explaining the psychological mechanisms leading from emulation to the internalisation of the emulated characteristics of the role model. However, by tidying up his account and adding bits and pieces to it where necessary, it is possible to make sense of those mechanisms, at least in rough outline (see Zagzebski 2017; Kristjánsson 2020b, Chap. 7). One can thus hypothesise that the process of role modelling starts with the overall positively valenced admiration of an exemplar, which leads to a conception of oneself as lacking the admired qualities but desiring to possess them, which in turn evokes emulation - that is, as long as the admiration is strong enough to elicit inspiration rather than just inert admiration from a distance of some glorious hero, deemed far beyond reach. Notably, admiration and inspiration do not feature in the simply story that 
Aristotle tells about the emulation of moral exemplars; those emotions will need to be added to make the story more psychologically nuanced and plausible. I have elsewhere complained about the lack of attention in Aristotle (and, for that matter, in the revisionary account by Zagzebski 2017, also) of another route to moral learning: elevation vis-à-vis abstract moral ideals where one is inspired, so to speak, by exemplarity itself rather than an exemplar (Kristjánsson 2020b, Chap. 7). However, I have another complaint to make here, drawing on Hoyos-Valdés general misgiving (2018, p. 67) about reducing all moral learning from inspiring others (including character friends) to Aristotle's emulation-model or Zagzebski's admiration-emulation one.

Sherman (1987, p. 610) explicitly states that character friends 'are eminently suited as models for emulation'. Although this claim follows her rehearsal of Aristotle's zelos, it is not entirely clear whether Sherman is using 'emulation' in Aristotle's technical sense or a broader colloquial sense in which it simply indicates that character friends are ideal models for moral learning. While the latter is somewhat platitudinous if one endorses Aristotle's view of what character friends are for, the former claim is problematic because it falls afoul of the following intuition that I hope readers share with me. It strains credulity towards the breaking point to think of the way our character develops through interactions with friends simply in terms of positively valenced admiration and negatively valenced emulation. I may be inspired to internalise the virtue of forgiveness to an enhanced extent by admiring Nelson Mandela's display of it, and then feeling inadequate in not matching him in this respect. However, given the psychological intimacy with a character friend and the idea of her as 'another self', it seems simplistic, at best, perverse, at worst, to consider my gradual internalisation of a stronger trait of forgiveness through my interactions with her in terms of simply, on the one hand, admiring her from the outside, as it were, and then, on the other, feeling bad that I am not as developed as her qua forgiver. This model may work perfectly for what are normally called 'role models' (of the Nelson Mandela or Mother Teresa kind) in the character-education literature, but surely the psychological mechanisms of learning from a character friend are much more complex, having to do with the affection shared between the two parties, to the extent that my relationship with her is qualitatively more advanced than the one I have with the standard role model.

I will try to entangle some of the possible mechanisms involved in learning from a character friend in the following section. However, to make initial sense of the conceptual and empirical distinctions that I want to draw, I am persuaded to offer here a model of persons as sources of character development (seen from the perspective of the beneficiary, see Table 1) that involves considerable tightenings of ordinary language, in the service of clarification and precision, especially with regard to the concepts of a role model and a moral exemplar (as a 'good' role model). Notably, I am no great fan of radical departures from the common usage of terms, however unsystematic it may be, inter alia because such departures can easily trap theorists inside ivory towers and hinder practical applications.

Table 1 Persons as sources of character development

Morally equal Morally unequal (superior) char- Morally superior non-character
character friend acter friend friend

\begin{tabular}{llll}
\hline Role model & $\varnothing$ & $\varnothing$ & $\begin{array}{c}\text { Moral exemplar, e.g. Nelson } \\
\text { Mandela }\end{array}$ \\
Non-role model & Soulmate & $\begin{array}{c}\text { Mentor, e.g. parent, teacher, pro- } \\
\text { fessor, more virtuous peer }\end{array}$ & $\begin{array}{c}\text { (Lots of people who might, but do } \\
\text { not, influence me) }\end{array}$ \\
\hline
\end{tabular}


However, I ask readers to bear with me, for the purposes of the present article, and give the following conceptual distinctions a fair hearing, even though they may not like the particular terms I use to convey them.

Recall that, for Aristotle, a relationship with a friend must be entered into non-instrumentally: for example, not with the primary intention of securing incremental character gain rubbed off from the friend. Moreover, the goodwill must be reciprocated: the friend must value/love me in the same non-instrumental way as I value/love her. In unequal friendships Aristotle adds the condition that the stronger party be 'loved more than he loves, for when the loving reflects the comparative worth of friends, equality is achieved in a way' (1985, p. 221 [1158b26-29]), but this does not subvert the point that the stronger party also loves the weaker one non-instrumentally.

In contrast, then, let me stipulate that a relationship with a role model is (a) instrumental in nature: initiated for the sake of character development and (b) asymmetric (or unilateral) in the sense that the (perceived) benefactor is not also at the same time a beneficiary of the (perceived) relationship, nor reciprocates the beneficiary's feelings. This obviously rules out the possibility that a role model can also be a character friend, which narrows down the ordinary-language meaning of 'role model' - although it still allows for the possibility that a role model can be a friend for utility and/or pleasure. Unequal character friends may seem to present an intermediate case, in terms of psychological proximity versus distance, but they still count as 'friends' rather than 'role models' in the above model because they fail to satisfy conditions (a) and (b) for role models. I think the term 'mentor' is most felicitously reserved for those friends.

In this model, a role model is a non-character friend, and insofar as she is morally superior to the beneficiary, she counts as a 'moral exemplar'. Parents, teachers and professors can fall into this category but, ex hypothesi in the present model, only in those cases where they are not character friends of the beneficiaries. This model may seem to have the counter-intuitive implication that common claims about a parent being at the same time 'my best friend and my greatest role model' do not make sense anymore. However, the reason we find this implication counter-intuitive is, I submit, because of our impoverished language in describing the mechanisms of learning to develop one's character through interactions with friends qua mentors rather than role models, and because of how bloated the term 'role model' has become in everyday discourse. The aim of this model is not so much to close down linguistic avenues as to open up new ones, which will be explored in the following section.

It is well known from the role-model literature that role modelling is a rickety ladder to climb because of the inter-related threats of uncritical hero-worship, moral over-stretching and moral inertia (Vos 2018; Kristjánsson 2020b, Chap. 7). There is good reason to conjecture that those threats will be mitigated when the benefactors are morally superior character friends (mentors) rather than just role models, precisely because of the greater psychological intimacy and mutual self-knowledge among character friends, where co-ordination with the friend replaces conformation to a role model (cf. Hoyos-Valdés 2018, p. 77).

Finally, in this model, I reserve the term 'soulmate' for a morally equal character friends from whom one learns to self-improve. There is nothing wrong as such with a broader understanding of 'soulmate' as covering all character friends qua kindred spirits (as I used the term earlier in this article); my intention is not to disrespect ordinary language by recoiling from it and suggesting that it must be replaced, across the board, with a new technical vocabulary. We simply need a handy term, in this model, to operationalise the notion of a morally equal character friend as a character developmental benefactor, and 'soulmate' fits that purpose well in this particular instance. 


\section{The Mechanisms of Learning from Character Friends}

No one has, to the best of my knowledge, written in any detail about how one develops one's character through interactions with close friends, let alone 'character friends' in the specific Aristotelian sense (barring some general suggestions in Telfer 1970-1971, and Hoyos-Valdés 2018). Despite its underlying educational focus, what Aristotle says about this himself is very meagre. In the absence of either a clear theory or specific empirical evidence, this section, on the putative mechanisms of learning from character friends, must therefore be seen as exploratory and tentative. I have in mind for now mainly examples of equal character friendships qua soulmateships. Most of what I say could plausibly apply to unequal character friendships as mentorships also, but further caveats and conditions would then have to be added for which there is no space here. Drawing broadly on the spirit rather than the letter of Aristotle's account, I propose to separate the mechanisms in question into three categories: emotional, cognitive-linguistic, and epistemological.

Character friendships arguably involve an emotional connection that is uniquely conducive to moral learning in terms of character improvement. The pride of place that Aristotle gives to emotions as part of the good life is well known (Kristjánsson 2018). While he does not single out emotions that are specific to character friendships, some candidates suggest themselves easily. The one I will focus on here is trust and, most notably here, mutual trust. A moral learner can also place trust in an elevated role model, but in most cases such trust will not be mutual; the standard role model may not even be personally acquainted with the learner. Trust is an essential emotion in some non-friendship-based social relationships, such as between a doctor and a patient, but there it is grounded in quite different motivational and dispositional structures to friendship and manifests itself differently (cf. Cocking and Oakley 1995, pp. 93-94). The unique feature of mutual trust, which is grounded in psychological intimacy and soulmateship, is that it steadies the mind, by providing what could be called existential security, and lowers psychological barriers of self-disclosure and self-receptivity, some of which are inimical to moral learning. For example, to meet someone who unhesitatingly bears moral witness to her faults and the temptations that she is facing can be an eye-opening experience for someone fighting the same demons. It will all be part of a mutual learning journey.

The second mechanism of learning that I propose to highlight here is linguistic and/ or cognitive and has to do with the mutual corrections that take place between friends as they discuss or debate their understandings of virtue terms (facilitating 'virtue literacy') and how the virtues are best applied in daily life. Mary Healy puts this in terms of young friends learning to practise their non-egoistic 'moral reasoning' with one another (2011, p. 449). There is an old saw that dialogue is only a Socratic, not an Aristotelian, method of moral education, but that seems ludicrous even when we think of early-years Aristotelian habituation with a moral tutor (who will surely explain her moral exhortations rather than just rely on the carrot and the stick), and even more so when we think of the advanced cultivation of phronesis-guided virtue that is ideally instantiated among character friends (Kristjánsson 2015, Chap. 6).

The notion of a 'critical friend' is paramount here-with the friend being not only a supporter but also a challenger (Gibbs and Angelides 2008). While that ideal may seem more at home in unequal character friendships, where the mentor gently 'corrects' the mentee, any constructive dialogue between equal character friends about how to deal with life's exigencies will involve critical engagement with the friend's point of view. Otherwise the friendship degenerates into what Brewer calls a 'static and complacent mutual admiration 
society' (2005, p. 726) and its very raison d'être is lost. As Cicero put it, to 'graciously give and receive criticism is the mark of true friendship' (2018, p. 155). Accepting criticism may even become a catalyst for profound epiphanic self-transformation (although Aristotle himself was sceptical of radical self-change in adulthood, see Kristjánsson 2020b, Chap. 6). To accept, unquestioningly, the friend's character flaws, without trying to correct them, is not a sign of true character friendship but rather its opposite: an attitude that in today's academic parlance would probably best be referred to as unhealthy 'co-dependency'. The critical engagement required by true friendship would, by Aristotle's lights, be guided by a mutual recognition of objective normativity inherent in the natural world in which we live. While understanding a soulmate involves understanding that person's unique self-narrative (Hoyos-Valdés 2018, p. 71), it thus also involves understanding that narrative against the background of shared character-relevant values. Nehamas's point (Nehamas 2016, p. 76, drawing on C. S. Lewis 1960), on how, in painting, friends tend both to look ahead, whereas lovers stare into each other's eyes, may be seen to represent this commitment to a common moral vision which is not only subjective, and not even relational in a dyadic sense, but lies beyond personal selfhood.

Speaking of 'selfhood' brings us neatly towards the third learning mechanism that I wish to foreground here, which I call the epistemological one, by drawing on Aristotle's much-cited locution of the friend as 'another self'. Debates have raged about whether Aristotle meant this simply as a poetic metaphor (i.e., about being as close as one can be to another person), or whether he was making a psychological claim (about the nature of kindred-spiritedness) or even an ontological one (about selfhood being somehow a relational concept). I will avoid getting embroiled in those exegetical issues here and just focus on two of the educational implications that Aristotle's locution is evidently meant to alert us to. To start with, here is the most relevant 'Aristotelian' quotation (I take it that the Magna Moralia was written by Aristotle or at least a faithful follower):

Now we are not able to see what we are from ourselves [...]; as when we wish to see our own face, we do so by looking into the mirror, in the same way when we wish to know ourselves we can obtain that knowledge by looking at our friend (1915, 1213a15-22).

The first thing to note here is that although Aristotle was a self-realist, believing that selfhood is objectively identifiable and not reducible to mere self-concept, he also subscribed to the 'soft realist' credo that self-concept forms part of actual underlying selfhood, in the same way that the mirror which mirrors the furniture in a room is also part of that furniture (Kristjánsson 2010, Chap. 2). Aristotle thus considered it of paramount interest (e.g. in terms of our potential character growth) that our views about who we are correspond to who we really are 'deep down'. However, he realised that we are often lacking in self-transparency and need someone who knows us well to correct our self-conceptions. This is why contemporary neo-Aristotelians are sceptical of self-report instruments to 'measure' character and recommend peer-reports and other more objective measures for triangulation (Kristjánsson 2015, Chap. 3). So the first educational implication to be drawn from Aristotle's self-theory is that character friends are invaluable for self-knowledge in the sense that they (often) know us better than we do ourselves. For example, a soulmate is likely to notice much earlier than I do that I have lost my zest for life and am sinking into depression. In general, 'we are able to observe our neighbours more than ourselves, and to observe their actions more than our own' (Aristotle 1985, p. 258 [1169b33-35]).

However, there is a second and perhaps more controversial implication lurking inside the above citation, about which Andrea Veltman (2004), for one, has written a penetrating 
paper. Because of the co-ordination and resonance of souls, involved in true soulmateship, Aristotle clearly thinks that I can learn facts about myself-including my current state of character and its potential for growth-by looking at how my character friends react and act, as their reactions are likely to mirror mine (although the latter will be opaque to my own introspection). So there are actually two reasons for why 'the self-sufficing man will require friendship in order to know himself' $(1915,1213 \mathrm{a} 23-26)$.

I said that the second reason may be more controversial because it seems to assume that (a) we have privileged access to an understanding of other people's character traits-when we see those being exercised in action - that is somehow, in principle, unavailable in the case of our own traits, and (b) we can identify those viewed traits as being the same as our own, although lack of direct self-knowledge prevents us from having immediate access to the self-traits with which we are meant to juxtapose the friend's traits. Aristotle seems to forget here his own insistence on how good character is individually adjusted to persons' different temperaments and social situations so that people who would count as overall equal in virtue and able to form character friendships as soulmateships could, in fact, be very different in terms of detailed character profiles, rather than just character-look-alikes. One of them, could, for example, be strong already on compassion but weak on honesty but the other strong on honesty while weak on compassion.

My qualms over the second of those implications notwithstanding, Aristotle does make a strong case for self-examination being dependent upon other-examination, and selfknowledge upon other-knowledge: in particular the intimate knowledge that the character friend has of who I am. We are beings prone to self-deceptions and positive illusions about ourselves. Friends can correct for those, to a certain extent at least, either by direct criticism, as noted in the second mechanism of moral learning above, or simply by being there for us as a 'mirror' to look into.

This epistemological mechanism holds the key to understanding one highly contested claim about character friendship, namely that it cannot be executed between vicious people: a claim that turns many theorists off Aristotle's moralised account of deep friendship and towards an aestheticised one (see e.g. Nehamas 2016, esp. pp. 60-61). Almost the only good reason that Aristotle finds for the termination of character friendships is if the friend becomes 'incurably vicious' (1985, p. 244 [1165b15-35]). One can understand that claim fairly superficially as a counter-example to the proverb that the sun never becomes worse for shining on the dunghill. It may attest to character flaws in oneself to want to mingle with the vicious and doing so can, then, exacerbate those flaws. However, Aristotle is making a more profound claim here than just warning against the contagious perils of moral pollution. He offers an extended argument showing that complete vice precludes self-knowledge, which in turn precludes self-love; and as lack of self-love prevents one from loving others in the philia sense (Aristotle 1985, pp. 246-247 [1166b1-25]), the very foundations of any edifying character friendship have been shattered.

So the upshot of Aristotle's the-friend-as-another-self conceptualisation is actually quite radical. It is not only that we need character friends to achieve self-knowledge which, in turn, is necessary to enable us to (continue to) reform our character. Even more importantly, without some measure of (developmentally growing) self-knowledge we are unable to make true friends in the first place as, bereft of the capacity to love ourselves because we do not know who we are, we are also unable to extend those feelings to others and to identify a rightful place for them in our lives. 


\section{Concluding Remarks and Classroom Applications}

The whole tenor of Aristotle's discussion of all types of friendship is that they are developmentally constituted and, in their most complete form as character friendship, educationally executed. There is no such things as friendship per se, but rather friendship at a certain developmental niveau, with its specific developmental assets and liabilities: qualitatively differentiated according to its educational affordances (Kristjánsson 2020a). I have argued in this article that the raison d'être of character friendship is mutual character development. 'Good people's life together allows the cultivation of virtue' (Aristotle 1985, p. 259 [1170a11-13]).

In the preceding section I identified three educational mechanisms unique to character friendship. To demonstrate that these mechanisms carry traction outside of the hermetically sealed hothouse of Aristotelian scholarship it suffices to mention that they correspond substantially to the three 'fruits of friendship' that Francis Bacon identified much later: 'peace in the affections', 'support of the judgement' and the bringing together of the 'many kernels' that friendship has, 'like pomegranate', into a coherent whole (Bacon 1910-14, p. 59). It bears repeating that identifying these mechanisms is not the same as instrumentalising friendship. The person who forms character friendships just in order to gain selfknowledge, for example, has not so much misunderstood what character friendship is for as what such friendship really is. The following analogy from C. S. Lewis says all there is to say about instrumentalisation: 'Say your prayers in a garden early, ignoring steadfastly the dew, the birds and the flowers, and you will come away overwhelmed by its freshness and joy; go there in order to be overwhelmed and [...] nothing will happen you' (1960, p. 39).

The educational argument about character friendships may appear to have proceeded at a fairly high level of abstraction so far. What does it mean for actual educational practice? In other words, what would be the implications of taking the title of this article seriously, about character friendship as a 'method of moral education'? The first thing to note is that nothing I have said above undermines the educational value of standard role-model education, activated through admiration and emulation. Such education may be particularly apt for projecting on our mental screens visions of the good life, either for the sake of adoption or consolidation. It may even, contra Aristotle, inspire us towards radical (epiphanic) selfchange-although, again contra Aristotle, attraction to abstract ideals may be even better at leveraging such change (Kristjánsson 2020b, Chap. 6). However, for the everyday 'plank by plank' (Hursthouse 1999, p. 165) revision and refining of our moral character traits, I think Aristotle was right: nothing beats the critical collaboration with close character friends who are psychologically intimate enough with us to know where the shoe pinches.

The most obvious educational implication of this view is that teachers should encourage the formation of close friendships between their students, young or old, and help enlighten them on the merits of turning those into true character friendships. To be sure, best-friendship dissolutions are often profoundly painful, and one may thus have some sympathy with the UK head teacher who discouraged pupils from forming 'best friendships' so as to avoid the pain and upset caused by fallings out (as reported in Healy 2015, p. 196, n. 1). However, for those who believe schools have any role to play in moral education-a view shared by the vast majority of teachers and parents-a no-best-friends policy in schools seems to be not only unduly paternalistic but, indeed, profoundly inimical to the moral development of the child (Healy 2017a). The idea that rather than to have a best friend, children should be 'friends with everyone' bespeaks an inadequate grasp of moral psychology and a conflation of the concepts of friendliness on the one hand and (true) friendship, on the other (cf. Healy 
2015). Taken to the other extreme, a strict utilitarian demand to maximise overall utility at every turn would put a positive non-supererogatory obligation on teachers to play 'friendship matchmakers', in order to enhance the flourishing of the greatest number of children in their care (cf. Collins 2013). While one may grumble that the strict utilitarian demand is counter-productive in the long run from the utilitarian perspective itself because of its extreme burn-out-threatening demandingness, in this case the excess of playing friendship matchmaker seems closer to the golden mean of appropriate teacher intervention than the deficiency of ignoring or discouraging the role of student friendships.

Should teachers take the extra step of offering themselves as unequal character friends (mentors) to children? Patricia White probably echoes the voices of many teachers when she argues that 'norms of impartiality' and the dangers of 'ethical complexities' rule out intimate friendships with individual students (1990, pp. 88-89). Contrast that view, however, with the Montessori approach to teacher-pupil relationships, according to which it is incumbent on every teacher to act in loco parentis and offer pupils domestic affection through frequent hugs and approaches towards deep personal friendships (Martin 1992, esp. pp. 16-19, 39). One could retort, first, that the Casa dei Bambini was a school type for a special kind of deprived children and, second, that more serious worries obtrude about potential abuse in the present age than in Montessori's time. However, nowadays no less than in decades past, there are children who-being shy, withdrawn or deprived of domestic affection-crave for that special attention from a significant adult, and by resisting friendships with such students, teachers are closing down spaces that would enhance their flourishing (see a moving example of teacher-pupil friendship in Shuffelton 2012). Moreover, teacher attention is not necessarily a zero-sum game. Showing a needy child special attention does not automatically mean than other, less needy, children are being neglected, from the point of view of impartiality. At any rate, viewing students as friends seems to be a healthier attitude than viewing them as clients or customers, as seems to be demanded by a neo-liberal agenda of schooling (cf. Noddings 2005, esp. p. 102).

White (1990, p. 87) does agree at least that teachers should encourage student friendships by taking them seriously and reinforcing them. How to do so obviously depends on the nature of the friendship in question (e.g. if it can be considered character friendship) and the age-related mode of the friendship, as it typically shifts from concerns with equality and reciprocity in children aged 8-12 to mutuality and understanding for those aged 9-14 (Rawlins 2008, pp. 39-40). Encouraging student friendship does not mean introducing 'friendship lessons' in schools or placing friendship explicitly on the school curriculum as a discrete subject matter (as noted by Healy 2017b, although a recent UK governmental document seems to recommend just that: Department for Education 2019). Nevertheless, it means incorporating discussions of friendship in any curriculum that is geared towards the moral education of the child, however conceptualised and labelled. What must be avoided at the same time is the unnecessary institutionalising of something that is deeply personal in nature; the sense of non-instrumentalism and voluntariness must be retained (cf. Enslin and Hedge 2019, on academic friendships). Ruehl's (2018) clarion call for a whole new educational framework grounded in a philosophy of friendship may sound like a menacingly radical idea. Yet, given the links between friendship and mutual trust, delineated above- not to mention the flow-like qualities, conducive to learning outcomes (Csikszentmihalyi 1990), supervening upon the actualisation of true friendship — the idea of turning the classroom into a community of character friendships may seem less radical and farfetched than it appears at first sight.

We become friends by practising friendships, just as we become musicians by playing music. The process of learning to become friends is thus essentially an educational 
process. Those are perhaps little more than truisms. However, I have proposed to make a more radical claim in this article: namely, that making close friends for character is not only an educational process but rather that its ultimate telos is educational at its very core. Aristotle's obscure references to the character friend as 'another self' are probably not best understood as references to human selves interwoven in some 'woolly pseudo-mystical way' (Hitz 2011, p. 17), but rather as remainders of the fact that cultivating deep friendships is an integrated collaborative activity, involving both an educational process and an educational outcome. My radical claim of character friendship as a 'method' of moral education may need to be modified and reframed if we choose to understand 'method' in a formal and operationalisable sense, such as a rigorous teacher-led Kohlbergian discussion about a moral dilemma in a classroom. However, if we understand 'method' here as a strategy that can be encouraged and nourished systematically by an educator (teacher, parent, etc.), for example through subtle hints and nudges, to help students grow morally, then there is nothing speaking against character friendships being referred to as a 'method' in this more permissive sense.

As iron sharpens iron, character friends sharpen each other and contribute towards collaborative moral growth, conducive to both individual and communal flourishing. Educators, at all levels of the school system, need to take note.

Open Access This article is licensed under a Creative Commons Attribution 4.0 International License, which permits use, sharing, adaptation, distribution and reproduction in any medium or format, as long as you give appropriate credit to the original author(s) and the source, provide a link to the Creative Commons licence, and indicate if changes were made. The images or other third party material in this article are included in the article's Creative Commons licence, unless indicated otherwise in a credit line to the material. If material is not included in the article's Creative Commons licence and your intended use is not permitted by statutory regulation or exceeds the permitted use, you will need to obtain permission directly from the copyright holder. To view a copy of this licence, visit http://creativecommons.org/licenses/by/4.0/.

\section{References}

Aristotle. 1915. Magna moralia (trans: St. George Stock). Oxford: Clarendon.

Aristotle. 1935. The Athenian constitution, the eudemian ethics, on virtues and vices (trans: Rackham, H.). London: William Heinemann.

Aristotle. 1985. Nicomachean ethics (trans: Irwin, T.). Indianapolis: Hackett Publishing.

Aristotle. 2007. On rhetoric (trans: Kennedy, G. A.). Oxford: Oxford University Press.

Bacon, F. 1910-1914. Essays: Vol. 3. Cambridge, MA: Harvard University Press.

Brewer, T. 2005. Virtues we can share: Friendship and Aristotelian ethical theory. Ethics 115 (4): 721-758.

Brooks, D. 2015. The road to character. London: Allen Lane.

Burnyeat, M.F. 1980. Aristotle on learning to be good. In Essays on Aristotle's ethics, ed. A.O. Rorty, 69-92. Berkeley: University of California Press.

Campodonico, A., M. Croce, and M.S. Vaccarezza. 2019. Moral exemplarism and character education: Guest editors' preface. Journal of Moral Education 48 (3): 275-279.

Cicero. 2018. How to be a friend (trans. Freeman, P.). Princeton: Princeton University Press.

Cocking, D., and J. Oakley. 1995. Indirect consequentialism, friendship, and the problem of alienation. Ethics 106 (1): 86-111.

Collins, S. 2013. Duties to make friends. Ethical Theory and Moral Practice 16 (5): 907-921.

Cooper, J.M. 1977. Aristotle on the forms of friendship. Review of Metaphysics 30 (4): 619-648.

Csikszentmihalyi, M. 1990. Flow: The psychology of optimal experience. New York: Harper Perennial.

Curzer, H.J. 2005. How good people do bad things: Aristotle on the misdeeds of the virtuous. Oxford Studies in Ancient Philosophy 28 (1): 233-256.

Damon, W., and A. Colby. 2015. The power of ideals: The real story of moral choice. Oxford: Oxford University Press. 
Darnell, C., L. Gulliford, K. Kristjánsson, and P. Panos. 2019. Phronesis and the knowledge-action gap in moral psychology and moral education: A new synthesis? Human Development 62 (3): 101-129.

Department for Education. 2019. Relationships: Education, relationships and sex education (RSE) and health education. London: Crown Publishers.

Enslin, P., and N. Hedge. 2019. Academic friendship in dark times. Ethics and Education 14 (4): 383-398.

Fowers, B.J., and A.R. Anderson. 2018. Aristotelian philia, contemporary friendship, and some resources for studying close relationships. In The theory and practice of virtue education, ed. T. Harrison and D.I. Walker, 184-196. London: Routledge.

Gibbs, P., and P. Angelides. 2008. Understanding friendship between critical friends. Improving Schools 11 (3): 213-225.

Healy, M. 2011. Should we take the friendship of children seriously? Journal of Moral Education 40 (4): $441-456$.

Healy, M. 2015. 'We are just not friends anymore': Self-knowledge and friendship endings. Ethics and Education 10 (2): 186-197.

Healy, M. 2017a. Should children have best friends? Studies in Philosophy and Education 36 (2): 183-195.

Healy, M. 2017b. After friendship. Journal of Philosophy of Education 51 (1): 161-176.

Hitz, Z. 2011. Aristotle on self-knowledge and friendship. Philosophers' Imprint 11 (12): 1-28.

Hoyos-Valdés, D. 2018. The notion of character friendship and the cultivation of virtue. Journal for the Theory of Social Behaviour 48 (1): 66-82.

Hursthouse, R. 1999. On virtue ethics. Oxford: Oxford University Press.

Jacquette, D. 2001. Aristotle on the value of friendship as a motivation for morality. Journal of Value Inquiry 35 (3): 371-389.

Kristjánsson, K. 2007. Aristotle, emotions and education. Aldershot: Ashgate/Routledge.

Kristjánsson, K. 2010. The self and its emotions. Cambridge: Cambridge University Press.

Kristjánsson, K. 2015. Aristotelian character education. London: Routledge.

Kristjánsson, K. 2018. Virtuous emotions. Oxford: Oxford University Press.

Kristjánsson, K. 2019. Ten un-Aristotelian reasons for the instability of Aristotelian character friendships. Journal for the Theory of Social Behaviour 49 (1): 40-58.

Kristjánsson, K. 2020a. Learning from friends and terminating friendships: Retrieving friendship as a moral educational concept. Educational Theory. (in press).

Kristjánsson, K. 2020b. Flourishing as the aim of education: A neo-Aristotelian view. London: Routledge.

Lewis, C.S. 1960. The four loves. London: G. Bles.

Marquez, G.G. 1988. Love in the time of cholera. London: Jonathan Cape.

Martin, J.R. 1992. The schoolhome: Rethinking schools for changing families. Cambridge, MA: Harvard University Press.

Nehamas, A. 2016. On friendship. New York: Basic Books.

Noddings, N. 2005. Critical lessons: What our schools should teach. Cambridge: Cambridge University Press.

Rawlins, W.K. 2008. Friendship matters: Communication, dialectics, and the life course. London: Aldine.

Ruehl, R.M. 2018. The value of friendship for education. Philosophy Now 126 (June/July): 14-17.

Sherman, N. 1987. Aristotle on friendship and the shared life. Philosophy and Phenomenological Research 47 (4): 589-613.

Shuffelton, A.N. 2012. Philia and pedagogy 'side by side': The perils and promise of teacher-student friendships. Ethics and Education 7 (3): 211-223.

Telfer, E. (1970-1971). Friendship. Proceedings of the Aristotelian Society, 71, 223-241.

Veltman, A. 2004. Aristotle and Kant on self-disclosure in friendship. Journal of Value Inquiry 38 (2): 225-239.

Vos, P.H. 2018. Learning from exemplars: Emulation, character formation and the complexities of ordinary life. Journal of Beliefs \& Values 39 (1): 17-28.

Wagner, L. 2019. Good character is what we look for in a friend: Character strengths are positively related to peer acceptance and friendship quality in early adolescents. Journal of Early Adolescence 39 (6): 864-903.

Walker, D.I., R. Curren, and C. Jones. 2016. Good friendships among children: A theoretical and empirical investigation. Journal for the Theory of Social Behaviour 46 (3): 286-309.

White, P. 1990. Friendship and education. Journal of Philosophy of Education 24 (1): 81-91.

Zagzebski, L. 2017. Exemplarist moral theory. Oxford: Oxford University Press.

Publisher's Note Springer Nature remains neutral with regard to jurisdictional claims in published maps and institutional affiliations. 